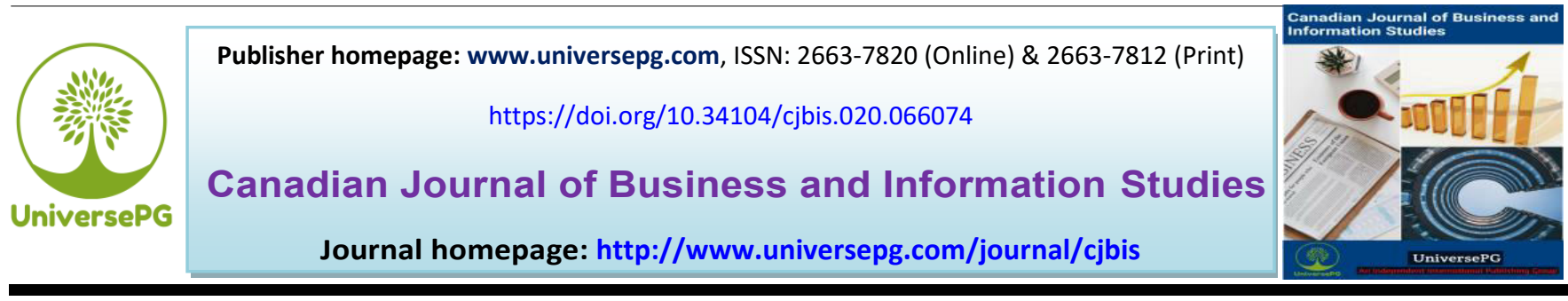

\title{
Human Capital Investment and Its Impact on Firm's Performance: A Study on Private Commercial Banks in Bangladesh
}

\author{
Mohammad Rafiqul Amin* \\ Department of Human Resource Management, Jatiya Kabi Kazi Nazrul Islam University (JKKNIU), Trishal, Mymensingh, \\ Bangladesh. \\ *Correspondence: abirshalo@yahoo.com (Mohammad Rafiqul Amin, Assistant Professor, Department of Human Resource \\ Management, JKKNIU, Trishal, Mymensingh, Bangladesh).
}

\begin{abstract}
Human capital is important possessions used to achieve a firm's competitiveness and it is through investment (the commitment of a firm's fund in human resource development with the hope of generating returns), we can expand it. This study embodies the investment scenario in human capital development made by different private commercial banks of Bangladesh and the impact of the investment on firm's performance. The researchers have used different HR metrics (Human Capital ROI, Net Profit after Tax per Employee, HR Expense Factor, Organizational Training Cost per Employee, Human Capital Value Added) to measure the impact of human capital investment on a firm's performance. Finally, the study reveals that investment in human capital development significantly increases a firm's performance.
\end{abstract}

Keywords: Investment, Human capital development, Firm's performance, HR metrics, Private commercial banks.

\section{INTRODUCTION:}

Human capital, the collective skills, information and skills of human beings that make contributions to organizational success is an asset to be leveraged to pressure cost and optimize organizational performance. In this know-how based totally economy, corporations are trying to find to optimize their group of workers via complete human capital improvement applications now not solely to gain commercial enterprise dreams however most vital is for a lengthy time period survival and sustainability. To accomplish this under taking, corporations will want to make investments assets to make sure that personnel have the knowledge, skills, and skills they want to work successfully in an unexpectedly altering and complicated environment. In response to the changes, now most companies have embraced the idea of human capital as a supply of aggressive benefit that will decorate greater performance. Hence, range is positively linked to higher trouble fixing and providing developing options (Michel \& Hambrick, 1992).

Nowadays human capital improvement will become a section of a usual effort to obtain cost-effectiveness and company performance. Hence, corporations want to apprehend human capital that would beautify worker pride and enhance performance. This lookup find out about shed lights on funding in human capital improvement and it's have an impact on firm's performance. At a glance, good sized research have been carried out on human capital and their implications on association overall performance have been broadly blanketed and obviously, human capital enhancement will end result in higher competitiveness and overall performance (Agarwala, 2003). 


\section{Literature review:}

The time period "human capital" has been described by means of Schultz, (1993) as a key aspect in enhancing a company belongings and personnel in order to enlarge productive as properly as maintain aggressive advantage. To maintain competitiveness in the company human capital turns into an instrument used to amplify productivity. Human capitals refer to techniques that relate to training, training and different expert initiatives in order to extend the tiers of knowledge, skills, abilities, values, and social property of a worker which will lead to the employee's pride and performance and in the end on a company performance. Rastogi, (2002) referred to that human capital is a vital enters for companies mainly for employees' non-stop enchantment in most cases on knowledge, skills, and abilities. Thus, the definition of human capital is referred to as "the knowledge, skills, competencies, and attributes embodied in persons that facilitate the introduction of personal, social and financial well-being" (Organization for Economic CoOperation and Development or OECD, 2001). The notion of human capital have in addition been described with the aid of Garavan et al. (2001) that human capitals have 4 key attributes as follows: (1) flexibility and adaptability (2) enhancement of man or woman advantage (3) the improvement of organizational advantage and (4) man or woman employability. It indicates that these attributes in flip generate add values to character and organizational outcomes. Becker, (1996) argues that there are special sorts of capitals that encompass schooling, a pc education course, and bills on clinical care. And in fact, lectures on the virtues of punctuality and honesty are capital too. In the authentic sense, they enhance health, elevate earnings, or add to a person's perception of literature over a lifetime. Consequently, it is totally in retaining with the capital thinking as historically described to say that charges on education, training, and scientific care, etc., are funding in capital. These are now not actually fees however funding with treasured returns that can be calculated

The continuously altering enterprise surroundings require companies to attempt for best aggressive blessings by way of dynamic enterprise plans which comprise creativity and innovativeness. This is genuinely vital for their lengthy time period sustainability. Undoubtedly, human capital performs an enormous function in improving firms' competitiveness (Barney, 1995). In addition, Doucouliagos (1997) has mentioned human capital as a supply no longer solely to inspire people and raise up their dedication however additionally to create expenditure in $\mathrm{R}$ \& amp; D and in the end pave a way for the technology of new information for the financial system and society in general. Also, for small groups it is a treasured asset, which is positively related with commercial enterprise performance. Becker, (1993) additionally referred to the most treasured of all capital is that funding in human being. Human capital has a direct affect on the mental capital property that will yield greater economic outcomes per employee. Therefore, improvement human capital has a direct have an effect on ROI of firms. A causal mannequin the use of a set of cross-sectional facts developed through Selvarajan et al. (2007) shows that human capital enhancement paves a way for larger innovativeness and this in flip gives fantastic implications on association performance. Some even encouraged that human capital improvement is a prerequisite to top economic overall performance (Delaney \& Huselid, 1996) and in addition, the significance of organizational human capital with regard to association overall performance was once in addition supported by way of Hsu et al. (2007).

In the meantime, human capital enhancement can additionally be considered in the context of pinnacle administration crew (TMT). Heterogeneity or every now and then is known as variety in TMT will have a tendency to lead to increased overall performance because the argument is heterogeneity promotes a variety of traits to be absorbed into the work pressure team; this consists of humans of extraordinary age groups, practical backgrounds, schooling backgrounds, tenure and gender. These traits have an advantageous affect on company overall performance as argued beneath the higher echelon idea (Hambrick \& Mason, 1984). Studies disclose that heterogeneity is positively linked to higher trouble fixing and providing innovative options (Michel \& Hambrick, 1992). Undoubtedly, heterogeneity (in the structure of human 
capital) can be a extensively essential enter to human capital improvement and enhancement as it makes corporations to be extra innovative and progressive for lengthy time period survival in their worldwide and international markets (Grossman, 2000).

We can say thru above literature that funding in human capital improvement is crucial to enhance organizational performance. In relation to this, the definition of association overall performance may want to fluctuate from one and another. Nonetheless, some clear definitions of company overall performance in the context of human capital enhancement should be put forward. In some cases, monetary overall performance measures such as proportion of income ensuing from new products, profitability, capital employed and return on property (ROA) (Selvarajan et al., 2007; Hsu et al., 2007). Besides, return on funding (ROI), income per share (EPS) and internet profits after tax (NIAT) can additionally be used as measures of economic overall performance (Grossman, 2000).

Interestingly, researchers additionally have a tendency to benchmark managerial accounting warning signs in opposition to the monetary measures in six dimension; 'workers compensation' (workers' compensation costs divided with the aid of sales); 'quality' (number of mistakes in production); 'shrinkage' (e.g. stock loss, defects, income return); 'productivity' (payroll fees divided via output); 'operating expenses' (total running costs divided through sales) (Wright et al., 2005). On the different hand, association overall performance can additionally be measured the use of 'perceived overall performance approach' (also referred to as subjective overall performance measure) the place Likert-like scaling is used to measure association overall performance from the pinnacle administration views (Selvarajan, 2007).

Since Banking enterprise of Bangladesh is developing extensively after the independence and contributing pretty to our human capital improvement as properly as monetary development, so our find out about tries to seem to be into the connection between human capital funding and its influence on firm's overall performance in this sector. Hence, this paper therefore, the following lookup query is used to information our UniversePG I www.universepg.com investigation: To what extent does funding in human capital create have an effect on company performance? While a whole lot of the argument in the literature in phrases of elements contributing to performance, this paper appears at one of the elements i.e. human capital.

\section{Review on banking industry in Bangladesh:}

Bangladesh's banking industry began its journey after independence with 6 nationalized commercialized banks, 2 state-owned specialized banks and 3 international banks. With the accession of private banks, the banking sector experienced major expansion in the 1980's. Now Bangladesh's banks are mainly of two types:

Scheduled Banks: Banks certified under the Bank Company Act, 1991 (Amended up to 2013) are named Scheduled Banks. There are 57 scheduled banks in Bangladesh operating under full Bangladesh Bank control and supervision that are empowered to do so through Bangladesh Bank Order, 1972 and Bank Company Act, 1991. Scheduled Banks are listed as follows:

State Owned Commercial Banks (SOCBs): There are 6 SOCBs that are wholly or substantially owned by the Bangladesh Government.

Specialized Banks (SDBs): 2 specialized banks which have been established for specific objectives such as agricultural or industrial development are now operating. These banks are also wholly or largely the property of the Bangladesh Government.

Private Commercial Banks (PCBs): There are 40 private commercial banks, most of which are private individuals' owners. PCBs can be subdivided into two groups:

Conventional PCBs: Now 32 traditional PCBs are active in the industry. In traditional fashion they execute the banking functions i.e. interest based operations.

Islami Shariah based PCBs: In Bangladesh, there are 8 Islamic Shariah based PCBs and they carry out banking activities according to Islamic Shariah-related principles i.e. The Profit-Loss Sharing mode (PLS). 
Foreign Commercial Banks (FCBs): 9 FCBs are operating in Bangladesh as the branches of banks that are established overseas.

Non-Scheduled Banks: The banks are called NonScheduled Banks, which are formed for particular and definite purposes and function under the acts enacted to fulfill those objectives. These banks are unable to execute all of the scheduled banking functions. Bangladesh now has 6 non-scheduled banks (https://www.bb.org.bd/fnansys/bankfi.php)

\section{Objectives of the Study:}

The primary objective of the study is to reveal the impact of investment in human capital development on firm's performance. Other specific objectives are -

1. To represent the scenario of investment in human capital development.

2. To illustrate the degree of leverage of human capital.
3. To determine return on human investments.

4. To represent the value created by employees, and

5. To illustrate the firm's efforts to develop employees abilities.

\section{METHODOLOGY:}

This analytical research is based on secondary information collected from different financial statements of private commercial banks Ltd. in Bangladesh. This study is conducted in total of 8 private commercial banks. This sample has been selected through convenient sampling method. The data used in this research is quantitive in nature. However, the theoretical part of this study is formalized from different books, journals, publications of thesis. Finally, the authors have used different HR metrics to analyze the data to measure the impact of human capital investment on firm's performance. The HR metrics are -

\begin{tabular}{|l|l|}
\hline HR Metrics & Formula \\
\hline Human Capital ROI & $\begin{array}{l}\text { Revenue - (Operating Expenses - Compensation + Benefits Costs) } \\
\text { / Compensation + Benefits Costs }\end{array}$ \\
\hline Profit after Tax per Employee & $\begin{array}{l}\{\text { (Revenue - Operating Expenses) - Tax \& Provisions }\} \text { / Number } \\
\text { of Full Time Equivalent Employees. }\end{array}$ \\
\hline Human Resource Expense Factor & Total HR Expenses / Total Operating Expenses. \\
\hline Human Capital Value Added & $\begin{array}{l}\text { Revenue - (Operating Expenses - Compensation + Benefits Costs) } \\
\text { / Number of Full Time Equivalent Employees. }\end{array}$ \\
\hline Human Resource Expense Per Employee & Total HR Expenses / Number of Full Time Equivalent Employees. \\
\hline Training Cost Per Employee & Total Training Cost / Number of Full Time Equivalent Employees. \\
\hline
\end{tabular}

\section{ANALYSIS AND FINDINGS:}

\section{Scenario of Investment in Human Capital Development:}

The following Table 1 shows the scenario of commitment of funds in human capital development by different Private Commercial Banks in Bangladesh for the period of the year 2014 to 2016 . Hence, we can say that proportion of funds invested in Human capital development by majority Private Commercial Banks in Bangladesh increased significantly.

\section{The Degree of Leverage of Human Capital:}

The degree of leverage of human capital means the percentage of funds invested in human capital development relative to total operating cost. The following Table 2 shows human resource expense factor which ultimately represents the degree of leverage of human capital by different Private Commercial Banks in Bangladesh for the period of the year 2014 to 2016. 
Table 1: Scenario of investment in Human Capital Development.

\begin{tabular}{|l|c|c|c|}
\hline \multirow{2}{*}{ Name of the Banks } & \multicolumn{3}{|c|}{ Human Capital Investment } \\
\cline { 2 - 4 } & $2014(\mathrm{TK})$ & $2015(\mathrm{TK})$ & $2016(\mathrm{TK})$ \\
\hline BRAC Bank Ltd. & $405,63,56,031$ & $463,80,70,483$ & $421,24,50,692$ \\
\hline Jamuna Bank Ltd. & $295,79,76,826$ & $224,36,27,373$ & $267,31,90,696$ \\
\hline Southeast Bank Ltd. & $141,92,58,208$ & $148,09,75,954$ & $194,16,68,434$ \\
\hline One Bank Ltd. & $183,34,00,006$ & $197,48,49,197$ & $227,54,49,383$ \\
\hline ShahjalalIslami Bank Ltd. & $178,64,87,554$ & $183,19,95,913$ & $196,87,14,169$ \\
\hline Standard Bank Ltd. & $152,50,58,026$ & $165,50,01,478$ & $172,85,99,496$ \\
\hline IFIC Bank Ltd. & $255,81,56,237$ & $233,20,69,298$ & $246,83,58,909$ \\
\hline Mercantile Bank Ltd. & $184,97,57,085$ & $189,47,62,865$ & $378,65,53,246$ \\
\hline
\end{tabular}

Table 2: Human Resource Expense Factor.

\begin{tabular}{|l|c|c|c|}
\hline Name of the Banks & $\mathbf{2 0 1 4}$ & $\mathbf{2 0 1 5}$ & $\mathbf{2 0 1 6}$ \\
\hline BRAC Bank Ltd. & $47 \%$ & $45 \%$ & $53 \%$ \\
\hline Jamuna Bank Ltd. & $97 \%$ & $67 \%$ & $67 \%$ \\
\hline Southeast Bank Ltd. & $43 \%$ & $41 \%$ & $45 \%$ \\
\hline One Bank Ltd. & $56 \%$ & $56 \%$ & $57 \%$ \\
\hline ShahjalalIslami Bank Ltd. & $65 \%$ & $64 \%$ & $63 \%$ \\
\hline Standard Bank Ltd. & $66 \%$ & $64 \%$ & $61 \%$ \\
\hline IFIC Bank Ltd. & $57 \%$ & $52 \%$ & $48 \%$ \\
\hline Mercantile Bank Ltd. & $50 \%$ & $46 \%$ & $84 \%$ \\
\hline
\end{tabular}

Hence, we can say that proportion of funds invested in Human capital development by majority Private Commercial Banks in Bangladesh relative to total operating cost is almost parallel. Note that expenses for human resource development cover major portion (about 60\%) of operating expenses (Milon, 2019).

\section{Analysis of return on human investments:}

Human Capital ROI or HCROI is an HR Metric that evaluates the financial value added by an organization's workforce against the money spent on them in terms of salaries and other benefits. The following Table 3 shows the percentage of profit obtained by a bank against every Taka invested in their human capital compensation.

The HCROI shows the ratio of income derived against the total employment costs (compensation and benefit cost) by different Private Commercial Banks in Bangladesh for the period of the year 2014 to 2016. It is seen from the table that HCROI represents a decreasing trend from the year 2014 to 2016 except for the BRAC Bank Ltd. and Shahjalal Islami Bank Ltd., where we can see the increasing trend of HCROI.

\section{Analysis of Profit after Tax per Employee:}

Measuring profit per employee can ensure a company is not overstaffed or understaffed. The following Table 4 shows that different Private Commercial Banks may have added employee team members to improve their revenues, but are they adding Taka to the bottom line? This HR metric will let Banks know if more is better, or whether their increased staffing is merely eating into their profits.

From the following table it is seen that Profit after Tax per Employee of the sampled Banks except Standard Bank Ltd. has increased significantly from the year 2014 t0 2016. It means that Private Commercial Banks in Bangladesh have been able to generate satisfactory return on their investment in intellectual capital. 
Table 3: Human Capital ROI.

\begin{tabular}{|l|c|c|c|}
\hline Name of the Banks & $\mathbf{2 0 1 4}$ & $\mathbf{2 0 1 5}$ & $\mathbf{2 0 1 6}$ \\
\hline BRAC Bank Ltd. & $280 \%$ & $276.31 \%$ & $323 \%$ \\
\hline Jamuna Bank Ltd. & $209.37 \%$ & $267.32 \%$ & $259 \%$ \\
\hline Southeast Bank Ltd. & $680.30 \%$ & $664.42 \%$ & $539 \%$ \\
\hline One Bank Ltd. & $310.58 \%$ & $311.18 \%$ & $293 \%$ \\
\hline ShahjalalIslami Bank Ltd. & $237.72 \%$ & $243.36 \%$ & $259 \%$ \\
\hline Standard Bank Ltd. & $352.07 \%$ & $298.42 \%$ & $287 \%$ \\
\hline IFIC Bank Ltd. & $224.33 \%$ & $256.59 \%$ & $240 \%$ \\
\hline Mercantile Bank Ltd. & $340.05 \%$ & $310.57 \%$ & $212 \%$ \\
\hline
\end{tabular}

Table 4: Profit after Tax per Employee.

\begin{tabular}{|l|c|c|c|}
\hline Name of the Banks & $\mathbf{2 0 1 4}$ & $\mathbf{2 0 1 5}$ & $\mathbf{2 0 1 6}$ \\
\hline BRAC Bank Ltd. & $2,89,798$ & $3,06,878$ & 701878 \\
\hline Jamuna Bank Ltd. & $6,13,764$ & $7,13,044$ & 730447 \\
\hline Southeast Bank Ltd. & $17,19,925$ & $12,97,340$ & 930839 \\
\hline One Bank Ltd. & $8,76,527$ & $9,46,294$ & 1193891 \\
\hline Shahjalal Islami Bank Ltd. & $3,48,867$ & $6,13,098$ & 761836 \\
\hline Standard Bank Ltd. & $7,80,821$ & $9,95,278$ & 546286 \\
\hline IFIC Bank Ltd. & $6,98,489$ & $4,24,725$ & 478752 \\
\hline Mercantile Bank Ltd. & $5,65,795$ & $5,94,614$ & 1090507 \\
\hline
\end{tabular}

Table 5: Human Capital Value Added.

\begin{tabular}{|lccc|}
\hline Name of the Banks & $\mathbf{2 0 1 4}$ & $\mathbf{2 0 1 5}$ & $\mathbf{2 0 1 6}$ \\
\hline BRAC Bank Ltd. & $15,56,127$ & $15,95,931$ & 2110541 \\
\hline Jamuna Bank Ltd. & $28,06,036$ & $25,98,721$ & 2810905 \\
\hline Southeast Bank Ltd. & $43,38,649$ & $40,07,353$ & 3990502 \\
\hline One Bank Ltd. & $30,51,667$ & $31,09,946$ & 3285308 \\
\hline ShahjalalIslami Bank Ltd. & $19,75,537$ & $20,62,667$ & 2325030 \\
\hline Standard Bank Ltd. & $34,47,185$ & $9,95,278$ & 2483066 \\
\hline IFIC Bank Ltd. & $22,51,219$ & $23,77,757$ & 2311743 \\
\hline Mercantile Bank Ltd. & $31,84,024$ & $27,58,757$ & 4672679 \\
\hline
\end{tabular}

\section{Analysis of Human Capital Value Added:}

Human Capital Value Added (HCVA) is an indicator, or measurement, of the financial value (profit) an average employee brings to an organization. The following Table 5 shows the average profit per employee or to what extent does the average employee contributes to the bottom line. The table shows that HCVA of most of the sampled Banks increased from the year 2014 to 2016.

\section{Analysis of Human Resource Expense per Employee:}

This is efficiency metric. These metric shows the cost efficiency of HR expressed in Taka. The following Table 5 shows that the human resource expense per employee of sampled banks except standard bank has an increasing trend from the period of year 2014 to 2016 which means that banks are not cost efficient in respect of Human Resource. 
Table 6: Human Resource Expense per Employee.

\begin{tabular}{|l|c|c|c|}
\hline Name of the Banks & $\mathbf{2 0 1 4}$ & $\mathbf{2 0 1 5}$ & $\mathbf{2 0 1 6}$ \\
\hline BRAC Bank Ltd. & $5,62,212$ & $5,84,582$ & 662857 \\
\hline Jamuna Bank Ltd. & $13,42,095$ & $9,73,797$ & 1090209 \\
\hline Southeast Bank Ltd. & $6,39,018$ & $6,23,306$ & 742228 \\
\hline One Bank Ltd. & $9,85,169$ & $9,99,418$ & 1122016 \\
\hline Shahjalal Islami Bank Ltd. & $8,32,861$ & $8,49,720$ & 898546 \\
\hline Standard Bank Ltd. & $9,81,376$ & $10,31,797$ & 867770 \\
\hline IFIC Bank Ltd. & $10,12,329$ & $9,36,950$ & 973328 \\
\hline Mercantile Bank Ltd. & $5,65,795$ & $5,94,614$ & 1853428 \\
\hline
\end{tabular}

\section{Analysis of Human Resource training cost per Employee:}

This metric determines how much money an organization spends on employee training. We calculate it by determining the cost of employee training, and some businesses include the labor cost of employee hours spent in training classes as well. Also include the travel costs, course fees, the cost of your learning management system, and the time spent administering employee training, such as setting up courses and printing certificates (Saha et al., 2020). The following Table 7 shows that training cost per employee of the sampled banks except one bank limited has increased from the period of year 2014 to 2016 which means that private commercial banks in Bangladesh are giving efforts in training and developing their employees in boosting their banking services efficiently.

Table 7: Training Cost per Employee.

\begin{tabular}{|l|l|l|l|}
\hline Name of the Banks & $\mathbf{2 0 1 4}$ & $\mathbf{2 0 1 5}$ & $\mathbf{2 0 1 6}$ \\
\hline BRAC Bank Ltd. & 6,298 & 6,563 & 9955 \\
\hline Jamuna Bank Ltd. & 1,876 & 1,647 & 2273 \\
\hline Southeast Bank Ltd. & 1,258 & 1,452 & 2194 \\
\hline One Bank Ltd. & 2,609 & 2,009 & 1874 \\
\hline Shahjalal Islami Bank Ltd. & 1,842 & 2,136 & 2061 \\
\hline Standard Bank Ltd. & 2,278 & 2,837 & 2985 \\
\hline IFIC Bank Ltd. & 8,778 & 10,260 & 10173 \\
\hline Mercantile Bank Ltd. & 6,454 & 6,722 & 5218 \\
\hline
\end{tabular}

\section{CONCLUSION:}

The objective of the study was to find out the investment scenario of investment in human capital development and assess the impact of investment in human capital development on performance by Private Commercial Banks in Bangladesh. The findings of the research reflect that sampled banks have significant amount of investment in human capital development evidenced by significant total investment in human capital, higher degree of leverage of human capital, UniversePG I www.universepg.com increasing trend of investment in human resource training and development over the study period. Findings also reflect the visible link between the human capital development and the Banks' performance. Findings indicated growing trend of Human Capital ROI, Profit per Employee, and Human Capital Value Added over the studied period. Some banks were unable to make proper investment on Human Capital Development and to generate satisfactory return over such investment. Undoubtedly, 
only the quality resource, in this case - the developed human capital is the organizations economic and employee's development basis. Therefore Banks should implement the human capital development policies that enhance human potential to ensure desired performance.

\section{ACKNOWLEDGEMENT:}

This study was supported with proper help and guidance in the Dept. of HRM, JKKNIU, Trishal, Bangladesh. Heartiest thanks to Dept. of HRM, JKKNIU, Bangladesh.

\section{CONFLICT OF INTERESTS:}

The researcher announces that they have no competing interests in the research.

\section{REFERENCES:}

1. Agarwala, T. (2003). Innovative human resource practices and organizational commitment: An empirical investigation. International Journal of Human Resource Management, 14(2), 175-197.

https://doi.org/10.1080/0958519021000029072

2. Barney, J. B. (1995). Looking inside for competitive advantage. Academy of Management Executive, 9(4), 49-61.

https://doi.org/10.5465/ame.1995.9512032192

3. Becker, B., \& Barry, G. (1996). The impact of human resource management on organizational performance: Progress and prospects. Academy of Management Journal, 39(4), 779801.

https://www.jstor.org/stable/256712?seq=1\#met adata_info_tab_contents

4. Becker, G.S. (1993). Human Capital: A Theoretical and Empirical Analysis with Special Reference to Education (3rd ed.). Chicago: University of Chicago Press, 402 pages, ISBN: 0-226-04119-0.

https://www.nber.org/books/beck94-1

5. Delaney, J. T., \& Huselid, M. A. (1996). The impact of human resource management practices on perceptions of organizational performance. Academy of Management Journal, 39(4), 949-969. https://doi.org/10.2307/256718
6. Doucouliagos, C. (1997). The aggregate demand for labor in Australia: A Metaanalysis. Australian Economic Papers, Blackwell Publishing. 36 (69), 224-42. https://ideas.repec.org/a/bla/ausecp/v36y1997i69 p224-42.html

7. Garavan, T. N., Morley, M., Gunnigle, P., \& Collins, E. (2001). Human Capital accumulation: The role of human resource developpment. Journal of European Industrial Training, 25(2/3/4), 48-68. https://eric.ed.gov/?id=EJ625884

Grossman, R. J. (2000). Measuring up: Appropriate metrics help HR prove its worth. $H R$ Magazine, 45(1), 28-35.

https://www.shrm.org/hr-today/news/hr-magazi ne/pages/measuring-up-appropriate-metrics-hel p-hr-prove-its-worth.aspx

8. Hambrick, D. C., \& Mason, P. A. (1984). Upper echelons: The organization as a reflection of its top managers. Academy of Management Review, 9, 193-206. https://doi.org/10.2307/258434

9. Hsu, I. C., Lin, C. Y. Y., Lawler, J. J., \& Wu, S. H. (2007). Toward a model of organizational human capital development: Preliminary evidence from Taiwan. Asia Pacific Business Review, 13(2), 251-275. https://doi.org/10.1080/13602380701233547

10. Michel, J. G., \& Hambrick, D. C. (1992). Diversification posture and top management team characteristics. Academy of Management Journal, 35, 9-37. https://doi.org/10.2307/256471

11. Milon M., (2019). Present scenario of human resource management (HRM) practices in the life insurance companies: Bangladesh perspective. Can. J. Bus. Inf. Stud., 1(6), 1727.

https://doi.org/10.34104/cjbis.019.01727

12. Organization for Economic Co-operation and Development (OECD), (2001). The WellBeing of Nations: The Role of Human and Social Capital. Paris: OECD, 1-121. http://www.oecd.org/site/worldforum/33703702. $\underline{\mathrm{pdf}}$ 
13. Rastogi, P.N. (2002). Sustaining enterprise competitiveness is human capital the answer. Human System Management. 19(3), 193-203. http://citeseerx.ist.psu.edu/viewdoc/download?d oi=10.1.1.457.3552\&rep=rep1\&type $=$ pdf

14. Saha S, Sarker R, and Ahmed SM. (2020). Impact of Green Human Resource Management (GHRM) practices in garment industry: Bangladesh perspective, Int. $J$. Manag. Account. 2(2), 22-30. https://doi.org/10.34104/ijma.020.022030

15. Schultz, T. W. (1993). The economic importance of human capital in modernization. Education Economics, 1(1), 13-19.

https://www.tandfonline.com/doi/abs/10.1080/0 $\underline{9645299300000003}$
16. Selvarajan, T. T., Ramamoorthy, N., Flood, P. C., Guthrie, J. P., MacCurtain, S., \& Liu, W. (2007). The role of human capital philosophy in promoting firm innovativeness and performance: Test of a causal model. International Journal of Human Resource Management, 18(8), 1456-1470. https://doi.org/10.1080/09585190701502588

17. Wright P. M., Gardner L. M., Moynihan L.M., \& Allen M.R. (2005). The relationship between human resource practices and firm performances: Examining causal order. Personnel Psychology, 58, 409-446.

https://doi.org/10.1111/j.1744-6570.2005.004 $\underline{87 . x}$

Citation: Amin MR. (2020). Human capital investment and its impact on firm's performance: a study on private commercial banks in Bangladesh, Can. J. Bus. Inf. Stud., 2(4), 66-74. https://doi.org/10.34104/cjbis.020.066074 C) 